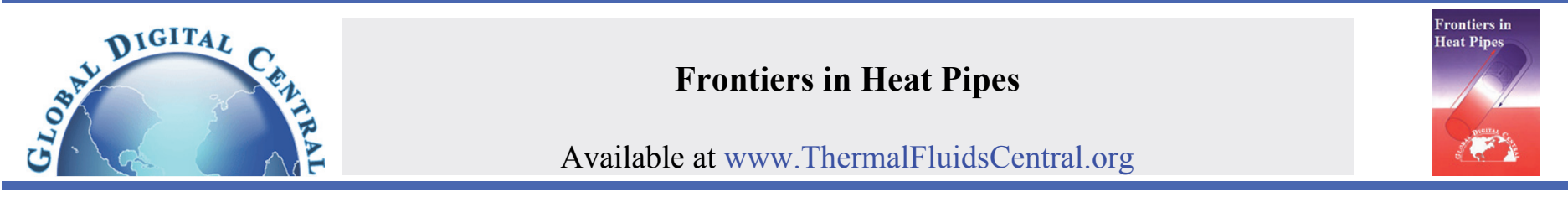

\title{
AN EXPERIMENTAL INVESTIGATION OF THERMAL PERFORMANCE OF CONVENTIONAL HEAT PIPE WITH WATER, ACETONE AND METHANOL AS WORKING FLUID
}

\author{
Roshan D. Bhagat* \\ Department of Mechanical Engineering, College of Engineering and Technology Akola, Maharashtra, 444104, India
}

\begin{abstract}
An experimentation investigation of thermal performance of conventional heat pipes (CHPs) with Water, Acetone and Methanol as working fluid determine the effect of heat transfer and overall system performance at a given constrained dimensional heat source. The experimental investigation included start-up time and temperature, the average, minimum, and maximum evaporator temperature during its operation, the overall heat transfer capability, and the overall thermal resistance of the system, also the behavior of conventional heat pipe under different heat inputs and with the different working fluids. To achieve the goal the experimental setup is fabricated and tested with three different working fluids Water, Acetone and Methanol with the filling ratio of $60 \%$. This work provides the detailed discussion on the thermal performance of CHP with Water, Acetone and Methanol as working fluid and behavior of CHP at different heat inputs.

Keywords: Thermal resistance, thermal performance, working fluid, heat input.
\end{abstract}

\section{INTRODUCTION}

The heat pipe (Faghri, 1995) is a highly effective passive heat transfer device for transmitting heat at high rates over considerable distances with extremely small temperature drops, exceptional flexibility, simple construction, and easy control with no external pumping power. Of the many different types of systems which transport heat, the heat pipe (Faghri, 1995) is one of the most efficient systems known today. The advantage of using a heat pipe over other conventional methods is that large quantities of heat can be transported through a small crossectional area over a considerable distance with no additional power input to the system. Furthermore, design and manufacturing simplicity, small end-toend temperature drops, and the ability to control and transport high heat rates at various temperature levels are all unique features of heat pipes.

The predecessor of the heat pipe, the Perkins tube, was introduced by the Perkins family from the mid-nineteenth to the twentieth century through a series of patents in the United Kingdom. Most of the Perkins tubes were wickless gravity-assisted heat pipes (thermosyphon), in which heat transfer was achieved by a change of phase (latent heat of evaporation). The Perkins tube design closest to the present heat pipe was patented by Jacob Perkins (1836). This design was a closed tube containing a small quantity of Water operating as a two-phase cycle.

The introduction of the heat pipe was first conceived by Gaugler (1944) of the General Motors Corporation in the U.S. Patent No. 2350348. Gaugler, who was working on refrigeration problems at that time, envisioned a device which would evaporate a liquid at a point above the place where condensation would occur without requiring any external power source. It consisted of a closed tube in which the liquid would absorb heat at one location causing the liquid to evaporate. The vapor would then travel down the length of the tube, where it would recondense and release its latent heat. It would then travel back up the tube via capillary pressure to start the process over. In order to move the liquid back up to a higher point, Gaugler suggested the use of a capillary structure consisting of a sintered iron wick. A refrigeration unit proposed by Gaugler used a heat pipe to transfer the heat from the interior of a compartment to a pan of crushed ice below.

In 1962, Trefethen (1962) resurrected the idea of a heat pipe in connection with the space program. Serious development started in 1964 when the heat pipe was independently reinvented and a patent application was filed by Grover at Los Alamos National Laboratory in New Mexico. Grover et al. (1964) and Grover (1966) built several prototype heat pipes, the first of which used Water as a working fluid, and was soon followed by a sodium heat pipe which operated at $1100 \mathrm{~K}$. Grover and his coworkers also demonstrated the effectiveness of heat pipes as a high performance heat transmission device and proposed several applications for their use. The recognition of the heat pipe as a reliable thermal device was initially due to the preliminary theoretical results and design tools that were reported in the first publication on heat pipe analysis by Cotter (1965).

Bhagat and Watt (2015) performed experimentation on closed loop pulsating heat pipe (CLPHP) with hydrocarbon as working fluid and observed that the thermal resistance of CLPHP decreases with increase in heat input. The thermal resistance of CLPHP with Acetone as working fluid is less as compared to thermal resistance of Methanol at same heat inputs and filling ratio of $60 \%$ and from the experimentation, it was concluded that out of the two hydrocarbon working fluids, the thermal performance of Acetone is higher.

Working fluid is partially filled in the tube. The conventional heat pipe (CHP) has a condenser, evaporator and adiabatic section. As any other two phase passive thermal control device, heat is acquired from the source through the evaporator section transferring it to the working fluid. 
The working fluid then flows by the adiabatic section towards the condenser section.

The objective of the present work is to study the CHP with Water, Acetone and Methanol as working fluid with four heat pipes. In the present work thermal performance of CHP with Water, Acetone and Methanol as working fluid is investigated at different heat inputs having filling ratio of $60 \%$.

\section{EXPERIMENTATION}

The purpose of this initiative was to combine fluid dynamics and heat transfer to create a device capable of transferring heat within the small distance. The first phase focused on fabricating the experimental setup and performing the initial testing to gain preliminary insight into its functionality. In addition to successfully transferring heat from heat source to the heat sink, this task provides an opportunity for experimental learning, device creation and targeted design through engineering principles.

\subsection{Setup Description}

\subsubsection{Working Fluid}

Working fluid is the most important factor that significantly influence on the thermal performance of CHP. Experimental setup consists of CHP with Water, Acetone and Methanol as working fluid. The boiling point of Water is $100^{\circ} \mathrm{C}$, Methanol $64^{\circ} \mathrm{C}$ and Acetone $57^{\circ} \mathrm{C}$, at 1 atmospheric pressure. $60 \%$ filling ratio has been used for Water, Acetone and Methanol.

\subsubsection{Copper Tube}

Compatibility of copper with Water, Acetone and Methanol as working fluid made it possible to use copper tube for preparing the experimental setup. The diameter of copper tube is 0.315 inch and length of $9.64 \mathrm{inch}$. The copper tube is $1.57 \mathrm{inch}$ dipped inside the evaporator section and 2.16 inch inside the condenser section. Along the 6.49 inch length of tube which is exposed to surrounding, a glass wool insulation is provided to prevent heat loss.

\subsubsection{Digital LASER Thermometer}

For measuring the evaporator temperature i.e. from $T_{1}$ to $T_{4}$ and condenser temperature from $T_{5}$ to $T_{8}$ as shown in fig. 1 the digital LASER thermometer is used. The digital LASER thermometer provides to flexibility to measure the temperature over the entire length of the copper tube.

\subsubsection{Evaporator Tank}

The evaporator tank design to the dimension of 8 inch $\times 6$ inch $\times$ 4 inch, so as to occupy the heating element and to have sufficient amount of Water inside the evaporator tank for heating the copper tube, with the Water bath heating is done.

\subsubsection{Condenser Tank}

The surface area of copper tube inside the condenser tank should be higher than the surface area of copper tube inside the evaporator tank hence the dimension of condenser tank is taken as 8 inch $\times 3$ inch $\times$ 3 inch. The condenser tank should hold sufficient Water so as to have heat rejection by the working fluid through the copper tube and to have condensation of working fluid.

\subsubsection{Coil Heater}

The coil heater with capacity of 500 Watt is used to heat the Water inside the evaporator tank.

\subsubsection{Temperature Indicator for Water Bath in Evaporator}

For measuring the Water bath temperature inside the evaporator tank, temperature indicator is used to monitor the temperature of Water bath so as to prevent the excessive heating of Water which may cause the dry out of working fluid in the copper tube.

\subsubsection{Variable AC Power Supply}

For changing the heat inputs to the coil heater variable AC power supply is used. 0-240 VAC can be adjusted with the help of dimmerstat. Digital voltmeter and ammeter are connected to show the voltage and current reading.

\subsubsection{Control Panel}

Digital voltmeter, ammeter and Water bath temperature indicator are mounted on the control panel.

\subsubsection{Tank Material}

Evaporator and condenser tank are prepared with acrylic. Acrylic is non conducting material and heat loss to the surrounding is kept minimum. Magnabond instant adhesive is used for preparing leak proof tank.

\subsection{EXPERIMENTATION AND TESTING OF CHP WITH WATER, ACETONE AND METHANOL AS WORKING FLUID.}

The experimentation performed on CHP by heating the Water bath with the help of coil heater. The heat inputs to the coil heater can be adjusted by using 0 to $240 \mathrm{VAC}$ power supply. Heat transfer by convection takes place from Water to the copper tube and heat is conducted through the copper tube, this heat is now transferred to the working fluid present inside the copper tube. This working fluid reject heat to the Water available in the condenser tank by sensible heat of liquid and latent heat of vapour.

The evaporator temperature $T_{1}$ to $T_{4}$ and condenser temperature $T_{5}$ to $T_{8}$ measure with the help of digital LASER thermometer. The eight temperature points are as shown in the fig. 1. The thermal resistance of CHP was calculated for the given heat inputs by taking the ratio of temperature difference between the evaporator and condenser to the heat input.

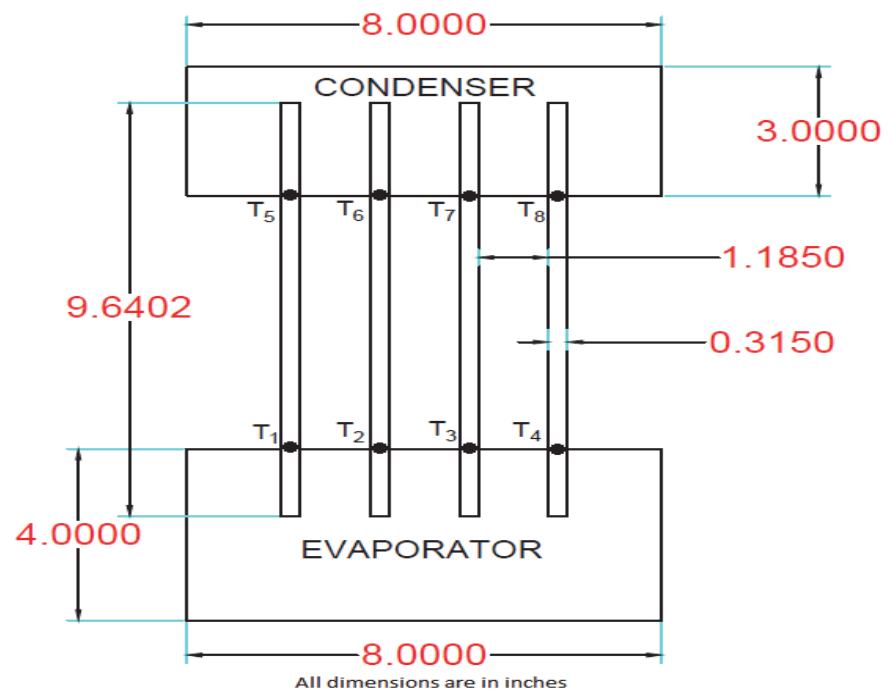

Fig. 1 Specification of experimental setup of CHP (all dimensions are in inches). 


\subsection{CAlCUlation}

The thermal resistance of CHP can be calculated by using the following equations,

$$
\begin{gathered}
R_{\text {thermal }}=\frac{T_{e}-T_{c}}{Q} \\
R_{\text {thermal }}-\text { Thermal resistance } \\
T_{e}-\text { Average evaporator temperature } \\
T_{c}-\text { Average condenser temperature } \\
Q-\text { Heat input } \\
Q=\text { Voltage } \times \text { Current }
\end{gathered}
$$

$$
T_{e}=\frac{T_{1}+T_{2}+T_{3}+T_{4}}{4}
$$

\begin{tabular}{|c|c|c|c|c|c|c|c|c|c|c|}
\hline S.N. & $\begin{array}{c}\text { Heat } \\
\text { input } \\
\mathrm{Q} \\
\text { in } W\end{array}$ & $\begin{array}{c}\text { Average } \\
\text { evaporator } \\
\text { temperature } \\
\text { Water } \\
i n^{0} C\end{array}$ & $\begin{array}{c}\text { Average } \\
\text { condenser } \\
\text { temperature } \\
\text { Water } \\
\operatorname{in}^{0} \mathrm{C}\end{array}$ & $\begin{array}{c}\text { Average } \\
\text { evaporator } \\
\text { temperature } \\
\text { Acetone } \\
\operatorname{in}^{0} C\end{array}$ & $\begin{array}{c}\text { Average } \\
\text { condenser } \\
\text { temperature } \\
\text { Acetone } \\
\text { in }^{0} \mathrm{C}\end{array}$ & $\begin{array}{c}\text { Average } \\
\text { condenser } \\
\text { temperature } \\
\text { Methanol } \\
\operatorname{in}^{0} \mathrm{C}\end{array}$ & $\begin{array}{c}\text { Average } \\
\text { evaporator } \\
\text { temperature } \\
\text { Methanol } \\
\operatorname{in}^{0} \mathrm{C}\end{array}$ & $\begin{array}{c}\text { Thermal } \\
\text { resistance } \\
\text { Water } \\
\text { in } K / W\end{array}$ & $\begin{array}{l}\text { Thermal } \\
\text { resistance } \\
\text { Acetone } \\
\text { in } K / W\end{array}$ & $\begin{array}{c}\text { Thermal } \\
\text { resistance } \\
\text { Methanol } \\
\text { in } K / W\end{array}$ \\
\hline 1 & 60.9 & 30.825 & 30.625 & 30.75 & 30.15 & 31.525 & 30.8 & 0.00328 & 0.00985 & 0.0119 \\
\hline 2 & 69.75 & 31.15 & 30.575 & 31.9 & 30.5 & 31.775 & 30.95 & 0.00824 & 0.02007 & 0.01183 \\
\hline 3 & 80 & 31.9 & 30.425 & 32.35 & 30.475 & 31.85 & 30.65 & 0.01844 & 0.02344 & 0.015 \\
\hline 4 & 90.1 & 32.325 & 30.375 & 33.525 & 30.575 & 32.075 & 30.775 & 0.02164 & 0.03274 & 0.01443 \\
\hline 5 & 99.9 & 32.5 & 30.525 & 33.8 & 30.725 & 32.7 & 30.825 & 0.01977 & 0.03078 & 0.01877 \\
\hline 6 & 112.1 & 33.15 & 30.375 & 34.95 & 30.9 & 34.25 & 30.825 & 0.02475 & 0.03613 & 0.03055 \\
\hline 7 & 123 & 33.425 & 30.275 & 35.175 & 30.825 & 35.3 & 30.9 & 0.02561 & 0.03537 & 0.03577 \\
\hline 8 & 136.5 & 36.85 & 31.175 & 36.05 & 30.95 & 35.9 & 30.8 & 0.04158 & 0.03736 & 0.03736 \\
\hline 9 & 149.6 & 37.725 & 31.1 & 36.85 & 31 & 35.75 & 30.725 & 0.04428 & 0.0391 & 0.03359 \\
\hline 10 & 163.3 & 38.2 & 31.1 & 37.175 & 31.075 & 36.225 & 30.95 & 0.04348 & 0.03735 & 0.0323 \\
\hline 11 & 177.6 & 38.6 & 31.075 & 38.1 & 31.1 & 38.625 & 30.95 & 0.04237 & 0.03941 & 0.04322 \\
\hline 12 & 192.5 & 39.575 & 31.175 & 39.925 & 31.225 & 41.125 & 31.6 & 0.04364 & 0.04519 & 0.04948 \\
\hline 13 & 209.3 & 39.725 & 31.9 & 40.275 & 31.65 & 40.625 & 31.45 & 0.03739 & 0.04121 & 0.04384 \\
\hline 14 & 225.45 & 41.2 & 31.15 & 44.125 & 31.425 & 42.075 & 32.1 & 0.04458 & 0.05633 & 0.04424 \\
\hline 15 & 242.2 & 41.55 & 31.05 & 43.175 & 31.425 & 44.55 & 32.375 & 0.04335 & 0.04851 & 0.05027 \\
\hline 16 & 261 & 43.2 & 31.05 & 44.8 & 31.45 & 49.925 & 32.75 & 0.04655 & 0.05115 & 0.0658 \\
\hline 17 & 277.5 & 44.625 & 31.35 & 44.45 & 31.725 & 48.4 & 33.05 & 0.04784 & 0.04586 & 0.05532 \\
\hline 18 & 296.05 & 45.475 & 31.325 & 44.4 & 31.8 & 48.825 & 33.25 & 0.0478 & 0.04256 & 0.05261 \\
\hline 19 & 316.8 & 45.875 & 31.125 & 45.85 & 32 & 51.2 & 33.625 & 0.04656 & 0.04372 & 0.05548 \\
\hline 20 & 338.25 & 46.875 & 31.575 & 49.75 & 32.2 & 52.55 & 33.775 & 0.04523 & 0.05188 & 0.05551 \\
\hline 21 & 357 & 47.775 & 31.575 & 50.05 & 32.7 & 53.1 & 33.725 & 0.04538 & 0.0486 & 0.05427 \\
\hline 22 & 378 & 48.45 & 31.725 & 51.3 & 32.775 & 53.05 & 33.425 & 0.04425 & 0.04901 & 0.05192 \\
\hline 23 & 396 & 50.1 & 31.675 & 50.95 & 33.05 & 55.225 & 33.575 & 0.04653 & 0.0452 & 0.05467 \\
\hline 24 & 421.8 & 50.1 & 31.625 & 55.525 & 33.625 & 55.9 & 33.9 & 0.0438 & 0.05192 & 0.05216 \\
\hline 25 & 444.6 & 52.25 & 31.9 & 56.025 & 33.425 & 56.725 & 34.05 & 0.04577 & 0.05083 & 0.051 \\
\hline 26 & 469.95 & 54.15 & 32.625 & 56.625 & 33.625 & 58.475 & 34.65 & 0.0458 & 0.04894 & 0.0507 \\
\hline 27 & 490 & 55.175 & 32.825 & 56 & 34.075 & 59.5 & 34.975 & 0.04561 & 0.04474 & 0.05005 \\
\hline 28 & 512.5 & 57.925 & 32.625 & 57.325 & 33.825 & 60.9 & 35.45 & 0.04937 & 0.04585 & 0.04966 \\
\hline 29 & 535.5 & 59.025 & 33.025 & 61.475 & 34.925 & 62.55 & 35.25 & 0.04855 & 0.04958 & 0.05098 \\
\hline
\end{tabular}

\section{Average condenser temperature}

is calculated by using the equation

$$
T_{c}=\frac{T_{5}+T_{6}+T_{7}+T_{8}}{4}
$$

Table 1 Thermal resistance of CHP with Water, Acetone and Methanol as working fluid 


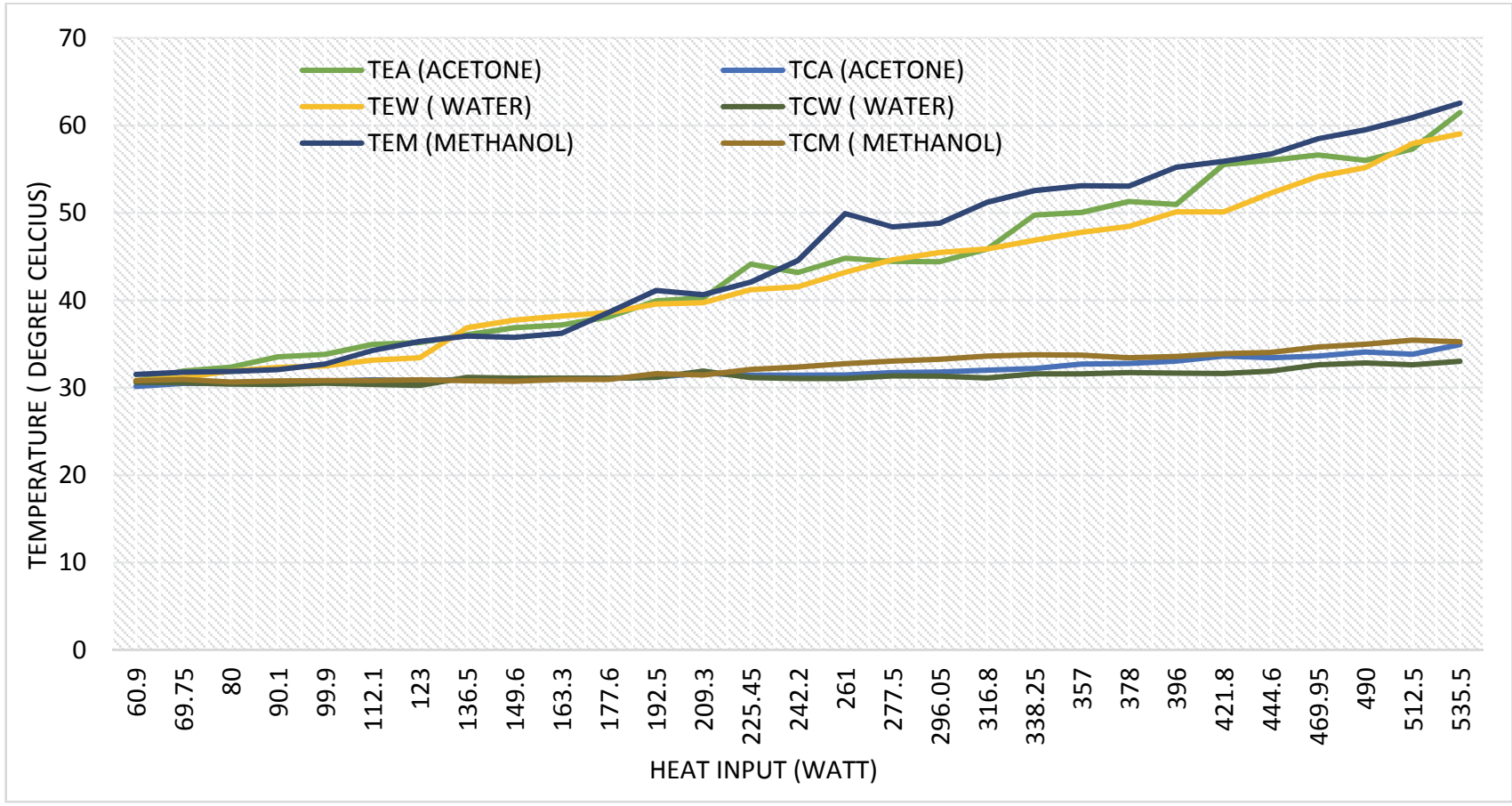

Fig. 2 Average evaporator and condenser temperature of CHP with Water, Acetone and Methanol as working fluid

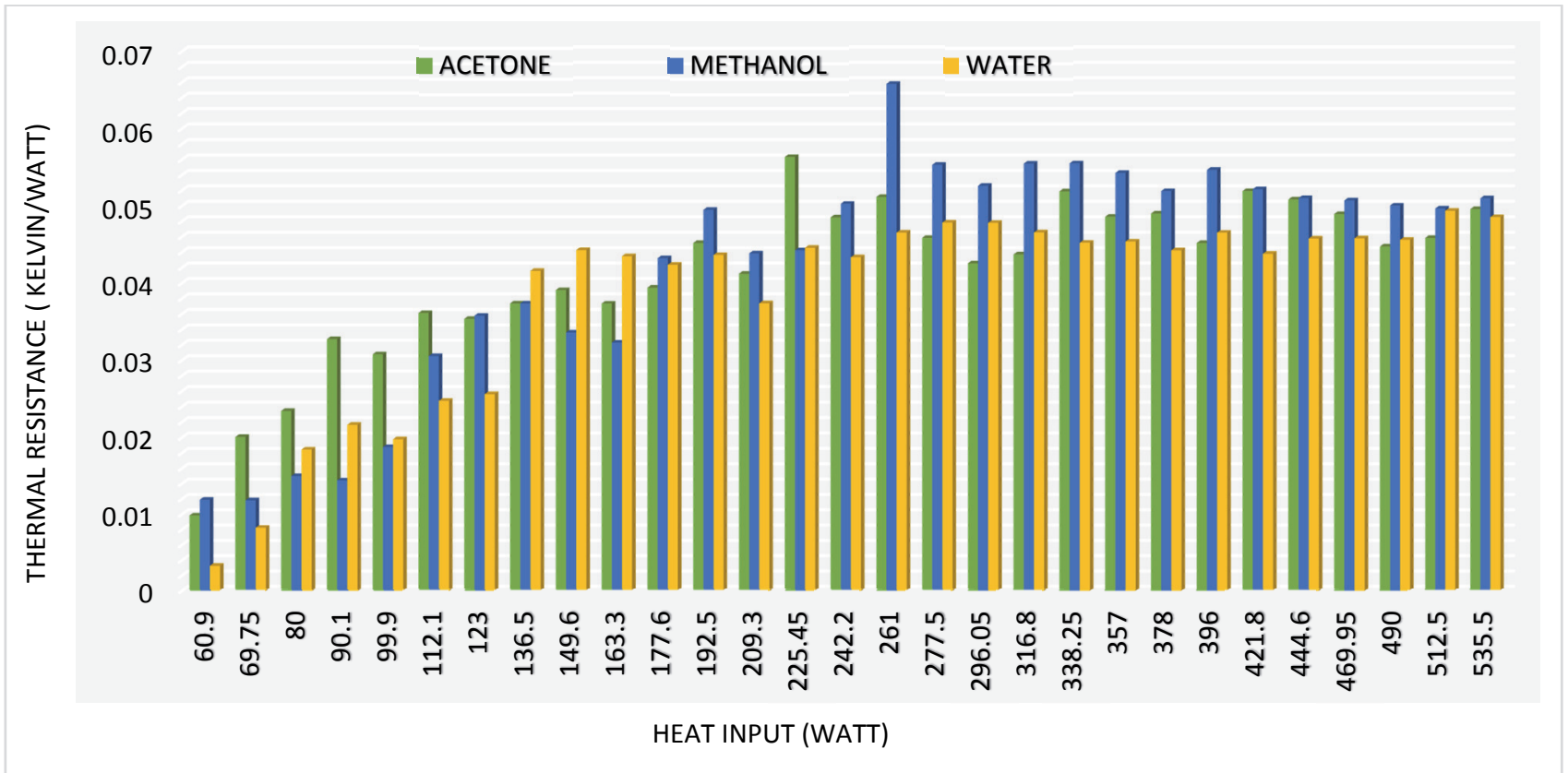

Fig. 3 Thermal resistance of CHP with Water, Acetone and Methanol as working fluid

\section{RESULT AND DISCUSSION}

\subsection{RESULT}

It was observed during the experimentation that, as the Water bath temperature increases there is increase in evaporator and condenser temperature of CHP. With increase in the heat input the thermal resistance of CHP increases for each of the working fluid. After comparing the thermal resistance of CHP with Water, Acetone and Methanol as working fluid, it was observed that at the same heat input and the filling ratio of $60 \%$ Acetone has higher thermal resistance than Methanol at lower heat input i.e. from 60.9 watt to 163.3 watt, but when the heat input is increase the thermal resistance of Acetone is lower than Methanol i.e. from 177.6 watt to 535.5 watt. Acetone has higher thermal resistance than Water at lower as well as at higher heat input i.e. from 60.9 watt to 535.5 watt with some exception of heat input from 136.5 watt to 177.6 watt. At higher heat input Water has less thermal resistance than Acetone and Methanol, and at the heat input from 136.5 watt to 163 watt the thermal resistance of Water is more than the thermal resistance of Acetone and Methanol. Methanol has higher thermal resistance than Water and Acetone at the heat input of 177.6 watt to 535.5 watt. 
The evaporator temperature for Methanol was found to be higher than Acetone and Water at the heat input from 225.45 watt to 535.5 watt, whereas, Water has lowest evaporator temperature from 225.45 watt to 535.5 watt. The evaporator temperature for Acetone is higher than Water and lower than Methanol from 225.45 watt to 535.5 watt.

\subsection{DISCUSSION}

The latent heat for Water is $2257 \mathrm{~kJ} / \mathrm{kg}$, the latent heat for Methanol is $1101 \mathrm{~kJ} / \mathrm{kg}$ while the latent heat for Acetone $523 \mathrm{~kJ} / \mathrm{kg}$, so the CHP with Acetone as working fluid can be used for lower heat application, because excessive heat can cause the dry out of working fluid. Methanol can be used for intermediate heat applications. Whereas, Water can be used for comparatively higher heat application. The advantage associated with Acetone due to lower latent heat is that it required less heat for converting liquid into vapour. CHP with Water as working fluid required more heat for converting liquid into vapour. Considerable loss of heat takes place from the length of heat pipe exposed to surrounding, hence glass wool insulation is provided making it an adiabatic section of $6.49 \mathrm{inch}$ length.

The effect of heat input and thermal resistance on thermal performance of CHP is not so clear from the fig. 3, as the results obtained are not straight forward either in terms of heat input increases and thermal performance increases or heat input increases and thermal performance decreases. Large variation in thermal resistance is observed at heat input from 60.9 watt to 535.5 watt, for all the three working fluids used i.e. Water, Acetone and Methanol. Also, it was observed from fig. 3 that the thermal performance of CHP with Water, Acetone and Methanol as a working fluid depends entirely on operating temperature range that the working fluid is subjected, i.e. working fluid may give higher thermal performance at lower heat input and may give lower thermal performance at higher heat input and vice versa.

\subsection{SOURCES OF ERRORS}

$>$ The temperature of tube from $T_{1}$ to $T_{8}$ is measured with the help of digital LASER thermometer, the accuracy of digital LASER thermometer depends on the distance to spot ratio. Hence, improper distance to spot ratio has possibility of creating errors while measurement of evaporator and condenser temperature.

$>$ For investigating the thermal performance of CHP with Water, Acetone and Methanol as working fluid, the temperature should be noted at ambient condition, there could be errors while the observations are recorded with three different working fluid i.e. water, acetone and methanol. If Water bath temperature is not same during experimentation.

$>$ Heat loss from Water to the surrounding should be minimize to maximum possible extent to avoid deceptive evaporator and condenser readings.

$>$ Heat loss from the heat pipe to the surrounding cannot be completely eliminated even though insulation is provided on heat pipe as digital laser thermometer is used because, it requires bare spot on heat pipe for measuring temperature.

$>$ Care should be taken to avoid excessive heat inputs which may cause drying out of working fluid in the tubes.

\section{CONCLUSION}

When Water bath temperature increases, there is increase in the evaporator and condenser temperature of CHP. The condenser temperature increases more rapidly when the Water bath temperature reaches to the boiling point of working fluid used in CHP. The thermal resistance of CHP with Water as working fluid is less as compared to thermal resistance of Acetone and Methanol at same heat inputs and filling ratio of $60 \%$. Hence from the experimentation, it can be concluded that out of the three working fluids, the thermal performance of Water is higher. CHP is a highly attractive heat transfer technology due to its excellent thermal performance, it is expected to meet the requirement for smaller heat transfer device which can transfer heat with minimum temperature difference.

\section{NOMENCLATURE}

$\begin{array}{ll}\text { CHP } & \text { Conventional heat pipe } \\ \text { CLPHP } & \text { Closed loop pulsating heat pipe } \\ \text { V } & \text { Voltage } \\ \text { I } & \text { Current } \\ \text { Q } & \text { Heat input } \\ \text { W } & \text { Watt } \\ \text { T } & \text { Temperature } i{ }^{0} C \\ \text { TEM } & \text { Average evaporator temperature of Methanol } \\ \text { TCM } & \text { Average condenser temperature of Methanol } \\ \text { TEA } & \text { Average evaporator temperature of Acetone } \\ \text { TCA } & \text { Average condenser temperature of Acetone } \\ \text { TEW } & \text { Average evaporator temperature of Water } \\ \text { TCW } & \text { Average condenser temperature of Water } \\ \text { VAC } & \text { Variable AC power supply } \\ \text { Rtherm } & \text { Thermal resistance }\end{array}$

\section{REFERENCES}

Harley, C., and Faghri, A., 1995, "Two-Dimensional Rotating Heat Pipe Analysis," Journal of Heat Transfer, 117(1), 202-208.

http://dx.doi.org/10.1115/1.2822304

Perkins, J., 1836, UK Patent No. 7059.

Gaugler, R., 1944, Heat Transfer Device, U.S. Patent No. 2350348.

Trefethen, L., 1962, "On the Surface Tension Pumping of Liquids or a Possible Role of the Candlewick in Space Exploration," G.E. Tech.Info., Serial No. 615 D114.

Cotter, T. P., 1965, "Theory of Heat Pipes," Los Alamos Scientific Laboratory Report No. LA-3246-MS.

Grover, G., 1966, "Evaporation-Condensation Heat Transfer Device," U.S. Patent No. 3229759.

Akachi H., Polasek F., Stulc P., 1990, "Pulsating Heat Pipes", Proceedings of $5^{\text {th }}$ International Heat Pipe Symposium, Melbourne, Australia, 208-217.

Khandekar S., Groll M., 2003, "On the Definition of Pulsating Heat Pipe”, Proceedings of $5^{\text {th }}$ Minsk International Seminar (Heat Pipes, Heat Pumps and Refrigerators), Minsk, Belarus.

Dadong Wang, Xiaoyu. Cui, 2010, "Experimental Research on Pulsating Heat Pipe with Different Mixtures Working Fluids", the $21^{\text {st }}$ International Symposium on Transport Phenomena 2-5 November, Kaohsiung City, Taiwan.

Narasimha K. R., Sridhara S.N., Rajagopal M.S., Seetharamu K.N., 2012, "Influence of Heat Input, Working Fluid and Evacuation Level on the Performance of Pulsating Heat Pipe", Journal of Applied Fluid Mechanics, 5(2), 33-42. 
Shafii M. B., Faghri A., Zhang Y., 2001, "Thermal Modeling of Unlooped and Looped Pulsating Heat Pipes", ASME Journal of Heat Transfer 123 (2001) 1159-1172.

http://dx.doi.org/10.1115/1.1409266

Charoensawan P., Khandekar S. Groll M., 2004, "Closed Loop and Open Loop Pulsating Heat Pipes", Proceedings of $13^{\text {th }}$ International Heat Pipe Conference, Shanghai, China, pp.21-25.

Khandekar S., Dollinger N., Groll M., 2003, "Understanding Operational Regimes of Closed Loop Pulsating Heat Pipes: An Experimental Study," Applied Thermal Engineering, 23, 707-719.

http://dx.doi.org/10.1016/S1359-4311(02)00237-5

Groll M., Khandekar S., 2004, “An Insight into Thermo-Hydrodynamic Coupling in Closed Loop Pulsating Heat Pipes," International Journal of Thermal Sciences, 43, 13-20.

http://dx.doi.org/10.1016/S1290-0729(03)00100-5

Groll M., Khandekar S., 2002, "Pulsating Heat Pipes: A Challenge and Still Unsolved Problem in Heat Pipe Science", Proceedings of $3^{\text {rd }}$ International Conference on Transport Phenomena in Multiphase Systems, Kielce, Poland, pp. 35-44 (ISBN 83- 88906-03-8).

Arab M., Soltanieh M., Shafii M., 2012, "Experimental Investigation of Extra-Long Pulsating Heat Pipe Application in Solar Water Heaters," Experimental Thermal and Fluid Science, 42, 6-15.

http://dx.doi.org/10.1016/j.expthermflusci.2012.03.006

Khandekar S., Groll M., Charoensawan P., Terdtoon P., 2002, "Pulsating Heat Pipes: Thermo-Fluidic Characteristics and Comparative Study with Single Phase Thermosyphon", Proceedings of $12^{\text {th }}$ International Heat Transfer Conference, ISBN-2-84299-307-1, 4, 459-464.

Charoensawan, P., Khandekar, S., Groll, M., Terdtoon, P., 2003 "Closed Loop Pulsating Heat Pipes- Part A: Parametric Experimental Investigations," Applied Thermal Engineering," 23(16), 2009-2020. http://dx.doi.org/10.1016/s1359-4311(03)00159-5

Khandekar, S., Charoensawan, P., Groll, M., Terdtoon, P., 2003, "Closed Loop Pulsating Heat Pipes- Part B: Visualization and Semi-Empirical Modeling," Applied Thermal Engineering, 23(16), 2021-2033,

http://dx.doi.org/10.1016/s1359-4311(03)00168-6

Soponpongpipat, N., Sakulchangsatjatai, P., Kammuanglue, N., Terdtoon, P., 2009, "Investigation of the Start-up Condition of a Closed Loop Oscillating Heat Pipe," Heat Transfer Engineering, 30(8), 626-

642.

http://dx.doi.org/10.1080/01457630802656876

Zhang, Y., Faghri, A., 2002, "Heat Transfer in a Pulsating Heat Pipe with Open End," International Journal of Heat Mass Transfer, 45, 755-764. http://dx.doi.org/10.1016/s0017-9310(01)00203-4

Shafii, M. B., Faghri, A., Zhang, Y., 2002, “Analysis of Heat Transfer in Unlooped and Looped Pulsating Heat Pipes," International Journal of Numerical Methods for Heat and Fluid Flow, 12(5), 585-609.

http://dx.doi.org/10.1108/09615530210434304

Tong B.Y., Wong T.N., Ooi K.T., 2001, “Closed Loop Pulsating Heat Pipe,” Applied Thermal Engineering, 21(18), 1845-1862. http://dx.doi.org/10.1016/S1359-4311(01)00063-1

Faghri, A., 2014, "Heat Pipes: Review, Opportunities and Challenges," Frontiers in Heat Pipes, 5, 1

http://dx.doi.org10.5098/fhp.5.1
Bhagat R.D., Watt K.M., 2014, "Closed Loop Pulsating Heat Pipe with Hydrocarbon as Working Fluid: A Review," International Journal of Science and Research, 3(10), 1576-1579.

Bhagat R.D., Watt K.M., 2015, "Effect of Dimensionless Number on Thermal Performance of Closed Loop Pulsating Heat Pipe: A Review, "International Journal of Science and Research, 4(2), 486-491.

Bhagat R.D., Watt K.M., 2015, “An Experimental Investigation of Methanol Closed Loop Pulsating Heat Pipe at Variable Water Bath Temperature," International Journal of Science and Research (IJSR), 4(2), 1157-1161.

Bhagat R.D., Watt K.M., 2015. "Effect of Water Bath Temperature on Evaporator and Condenser Temperature of Closed Loop Pulsating Heat Pipe with Acetone as Working Fluid," International Journal for Research in Engineering and Technology, 4(2), 383-387.

http://dx.doi.org/10.15623/ijret.2015.0402050

Bhagat R.D., Watt K.M., 2015, "Experimentation to Predict the Thermal Performance of Closed Loop Pulsating Heat Pipe with Acetone and Methanol as Working Fluid," International Journal for Research in Engineering and Technology, 4(4), 23-27.

http://dx.doi.org/10.15623/ijret.2015.0404005

Bhagat R.D., Watt K.M., 2015, "Performance Investigation of Closed Loop Pulsating Heat Pipe with Acetone as Working Fluid," International Journal for Research in Engineering and Technology, 4(4), 1-4. http://dx.doi.org/10.15623/ijret.2015.0404001

Bhagat R.D., Watt K.M., 2015, "Performance Investigation of Closed Loop Pulsating Heat Pipe with Methanol as Working Fluid", Proceedings of Mechanical Engineering Post Graduate Conference at PRMIT \& R Badnera-Amravati, MEPCON-2015. International Journal of Innovative and Emerging Research in Engineering, 2(1), 57-61.

Bhagat R.D., Watt K.M., 2015, "Effect of Bond Number on Thermophysical Properties of Working Fluid used in Closed Loop Pulsating Heat Pipe: A Review," International Journal of Science and Research (IJSR), 4(9), 544-551.

Bhagat R.D., Watt K.M., 2016, "Effect of Bond Number, Working Fluid and Operating Temperature on Thermal Performance of Closed Loop Pulsating Heat Pipe", International Conference of Science Technology and Sustainable Development Kuala Lumpur, Malaysia, Satellite Venue at PRMIT \& R Badnera-Amravati, ICSTSD 2016.

Bhagat R.D., Watt K.M., 2015, “An Experimental Investigation of Heat Transfer Capability and Thermal Performance of Closed Loop Pulsating Heat Pipe with A Hydrocarbon as Working Fluid" Frontiers in Heat Pipes, 6, 7

http://dx.doi.org10.5098/fhp.6.7

Bhagat R.D., Thakare S.R., Makwana S.C., 2016, "Experimentation To Predict the Thermal Performance of Conventional Heat Pipe with Water and Hydrocarbon as Working Fluid", International Journal for Research in Engineering and Technology, 5(3), 404-411.

https://doi.org/10.15623/ijret.2016.0503073

Bhagat R.D., Dhomane S.P., 2016, "Performance Investigation of Conventional Heat Pipe with Hydrocarbon as Working Fluid", International Journal for Research in Engineering and Technology, 5(3), 252-258.

https://doi.org/10.15623/ijret.2016.0503050 